\title{
第17回日本泌尿器科学会群馬地方会演題抄録
}

\section{＜臨床症例 $1>$}

座長 高橋 修（前橋赤十字病院）

\section{1. 外傷を契機に発症したと思われる左腎動脈塞栓症}

東 洋臣, 松尾 康滋, 高橋 修

矢島 久徳

（前橋赤十字病院）

腎動脈塞栓症は比較的稀な疾患と言われており, その 患者のほとんどが心房細動などの心疾患を有する. 心疾 患の既往がなく, 外傷を契機に発症したと思われる左腎 動脈塞栓症の 1 例を経験した. 症例は 62 歳の男性. 自動 車運転中に電柱に衝突し, 顔面及び胸・腹部を打ち近医 に入院した. 翌日, 腹痛, 嘔気が出現し当院外科紹介入 院となた. 腹部造影 CT で左腎の造影不良, 緊急に施行し た血管造影で左腎動脈は血栓でほぼ完全に閉塞してい た.アボキナーゼによる選択的腎動脈血栓線溶療法を施 行したが再開通は認められなかった。凝固・線溶系検査 でTAT, D-dimer, FPA などが高值を示し, なんらかの先 天性血栓傾向の存在が示唆され, それ外傷が加わり腎 動脈塞栓症が発症した可能性がある.

\section{2. 再発した右腎孟癌に対し, M-VAC 療法が著効した 1} 例

$\begin{array}{ll}\text { 森田 } & \text { 崇弘, 徳永 } \\ \text { 北浦 宏 } \\ \text { 大井 勝 }\end{array}$

新屋 博之

\section{卓, 登丸 行雄 \\ （桐生厚生総合病院） \\ (島田記念病院)}

(群馬大学付属病院)
40 歳, 男性. 主訴血尿. 右腎孟癌の診断で腎尿管全摘お よびリンパ節郭清を施行. 病理診断は pT3N2M0 stage IV. 傍大静脈リンパ節に転移を認めたが, 患者と相談, 補 助化学療法は施行せず外来経過観察とした. 術後 CA199 は 128(U/ml，<37) から 4 と正常化. 4 力月後, 腹痛・ 食欲不振が出現. 多発肺転移を認め再入院, CA19-9 は 419 と上昇していた. CT で多発肺転移, 肝転移抢よび傍 大静脈, 大動静脈間リンパ節腫大を認めた. M-VAC 療法 4コース施行, CA19-9 は 4 に下降し, 右肺径 $1 \mathrm{~cm}$ を除く すべての病変は CR と診断した. 残存肺転移巣を摘出し
日 時：平成 9 年11月15日(土) 15 時〜

場 所：刀城会館

会長代行：高橋 溥朋

事 務 局：群馬大学医学部泌尿器科内 清水 信明

たが肉芽・壊死・纎維組織で腫瘍組織をみとめず, $\mathrm{CR}$ が 確認された。

\section{CAPD による胸水と思われる一例}

川口 拓也, 羽鳥 基明, 松下 磐

(秩父市立病院)

林 雅道

(群馬大学)

症例は 52 歳女性. 1997 年 3 月慢性腎不全にて CAPD 導入. 1997 年 6 月, 軽度の呼吸困難, 排液量の減少, 体重 増加が出現し, 胸部 X-p にて右側胸水貯留を認めた. 一 時的に CAPD を中止し, 利尿剤の投与, 血液透析施行に て改善を認めた. 胸水貯留の原因として, 腹腔内圧の上 昇により腹腔と胸腔との間に交通が生じたことが考えら れた。腹腔内圧の上昇を避けるために少量頻回交換の CAPD を再開し，その後胸水貯留を認めていない.

\section{4. 後腹膜原発と考えられた悪性リンパ腫の一例 井上 雅晴, 中田 誠司, 竹澤 豊 小林 幹男, 栗原 寛（伊勢崎市民病院） 鈴木 豊 \\ (同病理部)}

症例は 84 歳, 男性. 主訴: 発熱, 左側腹部痛. 腹部 CT で左腎上極及び後方に造影されない腫瘤を認めたため受 診. 検査所見では, LDH の異常高值を認め, 分画では, 2 型が高值を示した. 腹部 CT で左腎上極及び後方に造影 されない腫瘤を認めた，確定診断のためエコー下に針生 検を施行したが標本が不適当なため診断にはいたらな かった. 患者の希望及び年齢を考慮し，対症療法のみを 行い一旦退院となっが, 右季肋部痛を訴え再入院となっ た. 腹部 CT では, 左腎孟の内部から不整に染まる腫腸が 頭側に大きく広がり，内側は腸腰筋から背部筋まで進展 していた，肺炎を併発しており，症状が悪化し死亡した。 病理解剖の結果, non Hodgkin's lymphoma, diffuse large cell type, Bcell subtype であった. 
5。慢性腎不全に合併した前立腺癌一酶酸リュープロレ リンの透析性を調查した一例

中田 誠司, 井上雅 晴, 竹澤 豊 小林 幹男, 栗原 寛（伊勢崎市民病院） 鈴木 豊 (同病理部)

症例は 67 歳, 男性. 腎不全のため当科外来を紹介受診 した. その時の PSA (TOSOH) が $13.4 \mathrm{ng} / \mathrm{ml}$ と高值で あった，触診，経直腸前立腺エコーでも前立腺癌が疑わ れ, systematic biopsyにて両葉に中分化腺癌がみとめら れた. 諸検査にて, T2bN0M0, Stage B 2 の診断であった. フルタミド $375 \mathrm{mg} /$ 日の内服を開始し, 8 日後に酢酸 リュープロレリンの皮下注射を施行した。皮下注射 1 日 後, 4 日後, 8 日後, 27 日後に扔ける血液透析前後の酢酸 リュープロレリンの血中濃度を測定したところ, 透析後 には透析前より約 10-20\%低下した。 また，27 日後の透 析後の值は，通常の患者に投与した時の值と大差なかっ た. PSA，テストステロンは順調に下降し，特記すべき副 作用もなく外来で経過観察中である. 慢性透析を行って いる患者は年々増加し, また透析患者には悪性腫瘍の合 併が多いことが指摘されている．酢酸リュープロレリン は，透析患者に発生した前立腺癌に対しても有用である ことが示唆された.

\section{6. リトクラストと TUR-P にて摘出した前立腺結石の} 1 例

\section{曲友弘, 小林大志郎, 町田 昌己 牧野 武雄, 柴山勝太郎}

\section{（公立富岡総合病院）}

43 歳, 男性. 97 年 2 月頃より残尿感, 排尿困難が出現 し, 検診で前立腺腫大を指摘された. 直腸診で小鶏卵大 の硬い前立腺を触知し, KUB・UG で $35 \times 30 \mathrm{~mm}$ の前立 腺結石を認めたため, リトクラスト, TUR-Pを施行した. 尿道前立腺部に石炭用の結石が突出していたため, リト クラストで砕石, 鉗子とエリック吸引器で摘出した. 続 いて TUR-P を施行し, 9.9g 切除した. 前立腺内腺内にも 黒色の小結石を認め，尿道の結石も前立腺由来と考えた. 結石重量は $10.6 \mathrm{~g}$ であった. シュウ酸カルシウム, リン酸 カルシウムが主成分で, 判定不能物を含んでいた. 術後 の膀胱部単純写真では残石は認めなかった. 本症例は, 前立腺腺腔内への尿の逆流などが原因となって結石が発 生, 成長して尿道に穿破した原発性外生前立腺結石であ ると考えた。

\section{<臨床症例 $2>$}

\section{座長 栗原 潤（原町赤十字病院）}

7. 小児膀胱尿管逆流に対するコラーゲン注入療法の経 験

\author{
小倉 治之, 鈴木 光一, 熊坂 文成 \\ 黒沢功 (黒沢病院)
}

症例は 5 歳, 女児. 腎孟炎をくり返すため精査し両側 膀胱尿管逆流を認めた. 右は 3 度, 左 4 度であった. 膀胱 内圧測定では低コンプライアンス膀胱の所見で，尿意は 無く, 神経因性膀胱による続発性 VUR と考えられた. 全 身麻酔下に経尿道的に $13.5 \mathrm{Fr}$ 操作用膀胱鏡を挿入し専 用の穿刺針にて両側尿管口 6 時の粘膜下にコラーゲンを 注入した. 手術時間は 31 分であった. 手術翌日より歩行 可とし術後 6 日めに退院となった. 術後の膀胱造影で, 右 VUR は消失, 左は不変であった. 左は注入部位が悪 かった可能性があり，再施行を予定している．内視鏡的 逆流防止術は成功率, 再発率の面で開腹術に若干劣るが, 侵襲が少なく，症例を選べば有用な方法と考えられる.

\section{8. 尿膜管囊腫の 1 例 \\ 富澤 秀人, 小澤 雅史, 真下 正道 猿木 和久 \\ （日高病院）}

症例は, 36 歳男性, 主訴は血精液症. 膀胱鏡にて頂部に 球状の粘膜突出を認め, 粘膜下腫瘍疑いにて膀胱部分切 除及び遺残尿膜管切除を行った. 病理学的診断は尿膜管 囊腫であった．本症は，感染を伴うことが多くBeggや Bilchert-Toft らによると，その約 75\%に炎症性変化を認 めるといわれている. 本症の予後は良好だが, 膀胱頂部 の囊胞性病変が必ずしも良性の尿膜管囊腫とは限らず, 尿膜管癌の可能性もあること, 尿膜管癌の予後が極めて 悪いこと, 成人の尿膜管疾患では, 小児に比べ悪性腫瘍 が多いという報告があること, Bourne らによると経尿道 的生検の信頼性に疑問があること, 手術侵襲の少ない術 式であることなどから，尿膜管囊腫が疑われた場合には， 膀胱部分切除を含めた囊腫切除を行うべきであると考え る. 以上，血精液症の精査中に偶然発見された膀胱粘膜 下病変としての尿膜管囊腫の経験を, 若干の文献的考察 を加え報告した。

\section{9. 根治的膀胱摘除術における自動縫合器, 超音波メス の使用経験}

川島 清隆, 宮本 重人, 高橋 溥朋

(足利赤十字病院)

根治的膀脱摘除術において出血量の減少, 手術操作の 確実性を得るため超音波駆動メス，自動縫合器を使用し 
た.エチコン社製の超音波駆動メス：HARMONIC

SCALPEL を用いて lateral pedicle の一部及び prostatic fascia を切離した.これは $55500 \mathrm{~Hz}$. の超音波振動による 機械的エネルギーにより組織の蛋白の変性, 切離を行う もので正確な切離と確実な止血を得られるが多少時間が かかるのが難点である. ついで lateral pedicleをエチコ ンエンドカッターETS フレックス 35 ミリにて切離した. 短時間で容易に無血的にまた小腸の吻合に pedicle の切 離が出来た．また小腸の吻合にプロキシメイトリニ ヤーカッター55ミリを用いた. 確実かつ簡便に十分な口 径を持つ吻合が得られた. 以上の工夫により出血量の減 少, 確実な手術操作が得られた. なお, 自動縫合器は保険 上は尿路変更術に於いて 6 発までである.

10. 副腎性器症候群に陰核肥大を合併した 1 例 横田 英巳, 峯岸 敬, 青木 宏
鹿沼 達哉, 伊吹 令人

(群馬大学産婦人科)

深堀 能立

(同泌尿器科)

陰核腫瘍は外来診療のなかであまり接する機会はない が, 今回我々は手術を試行し経過良好だった症例を経験 したので報告する. 患者は 19 歳 0 回経妊 0 回経産, 昭和 62 年 (8 歳)より平成 2 年まで性早熟症にて cyproterone acetate 投与にて治療. 平成 7 年より陰核腫大を認め外来 にて経過観察していたが, 平成 8 年 12 月頃より増大傾 向出現したためMRI 検査を試行したところ陰核海綿体 の肥大が認められた。 また副腎性器症候群の疑いもあり $\mathrm{ACTH}$ 負荷試験を行い $17 \alpha \mathrm{OHP}$ の上昇が認められ $3 \beta \mathrm{OH}$ ase 欠損症との診断. 陰核海綿体の外科的切除手術 目的にて平成 9 年 3 月 31 日入院となる. 同年 4 月 2 日, 陰核の周囲の海綿体組織の剝離除去術を施行. 術後の病 理組織検查では海綿体組織の過形成であった. また入院 中の腹部 MRI 及び CT 検査で脾腫大及び mulptile mass lesion が認められ内科にて経過観察中である.

副腎性器症候群 ( $3 \beta \mathrm{OH}$ ase 欠損症) に陰核腫大を合併 して陰核腫瘍の外科的切除を試行した症例を経験したの で報告する. 術後病理検查では海面体組織で腫瘍性病変 はないとの報告だった.
11. VIP 療法が奏功した非セミノーマステージII B の 1 例

\begin{tabular}{|c|c|c|c|c|}
\hline 増田 & 広, 小池 & 秀和, & 中里 & 晴樹 \\
\hline & 和浩, 清水 & 信明, & 黒川 & 公平 \\
\hline & 英壽 & & & （群馬大学） \\
\hline & 雄一 & & （利木 & 中央病院） \\
\hline & 隆久 & & （大旦 & リニック) \\
\hline & $\underline{E}$, & & 篠崎 & 利 \\
\hline
\end{tabular}

(善衆会病院)

33 歳男性. 左陰囊部腫脹を主訴に近医受診. 左精巣腫 瘍疑いにて平成 9 年 5 月 9 日左高位精巣摘除術施行. 精 査加療目的にて当科紹介入院となった. 摘出した腫瘍の 病理診断は複合型胚細胞腫瘍で, 下大静脈から左大腿静 脈にかけての腫瘍塞栓と大動脈に近接したリンパ節腫大 を伴う非セミノーマpT1N3M0 ステージII B と診断し, PEB 療法を第 1 コースで施行後, 計画的にVIP 療法を 2 コース目から 3 クール施行. 化学療法施行後腫瘍塞栓は 画像診断上消失し, リンパ節転移は $20 \%$ に縮小. 10 月 9 日後腹膜リンパ節郭清術施行. 摘出したリンパ節に未熟 奇形腫あり, 後療法を検討中である.

\section{<基礎的研究 >}

座長 深堀 能立 (群馬大学)

12. 幼弱ラットを用いた精囊および前立腺におけるエス トロジェン・レセプター（ER）の発現 中野 勝也, 中里 晴樹, 清水 信明 湯浅 久子, 深堀 能立, 山中 英壽

(群馬大学)

【目的】前立腺に対するエストロジェンの作用は，間 接的にアンドロジェンレベルを低下させることに加えエ ストロジェンの直接作用が示唆されている. その受容体 である E R 発現のオス性腺におけるメカニズムを知る目 的で, 幼若ラットのモデルを用い $\mathrm{E}$ Rの発現を調べた.

【方 法】コントロール群 (S), 去勢 (C) 群, 去勢十エス トロジェン投与 (CE) 群のそれぞれの精囊, 前立腺にお けるERの発現を RT-PCR 法でみた.

【結 果】精囊の C および CE 群で ER- $\alpha$ の発現をみた が, ER- $\beta$ の発現は認めなかった.一方前立腺では C およ びCE群でER- $\beta$ の発現の増強をみたが, ER- $\alpha$ の発現 は認めなかった。

【考 察】エストロジェンの前立腺に対する直接作用は ER- $\beta$ が強く関与していることが示唆された. 


\section{臨床的研究 $>$}

座長 深堀 能立 (群馬大学)

\section{3. 免疫抑制剤（タクロリムス）の体内動態の個体差に} ついて

関塚 雅之, 柁原 妙子, 小川 淳司
宮本 晶子, 大嶋 康男, 堀内 龍也 (群大病院薬剤部)

羽鳥 基明, 林 雅道, 山中 英壽

(同泌尿器科)

タクロリムスは体内動態の個体差が大きく治療濃度域 が狭いこともあり投与量の調節が難しい薬剤である。ま た，腎移植患者は腎機能不全から高血圧症を併発し Ca 拮抗薬を併用している場合が多い. タクロリムス, Ca 拮 抗薬は同一の薬物代謝酵素 CYP III A4 により代謝され るため, Ca 拮抗薬がタクロリムスの代謝を阻害し血中 濃度を上昇させると言われて扔り, 移植初期から薬物相 互作用の懸念がある. そこで, 群馬大病院でタクロリム スを用いた症例について体内動態と $\mathrm{Ca}$ 拮抗薬との相関 について検討した.

AUC において Ca 拮抗薬併用者は併用していない症 例と比べて高值を示し, 半減期も長くなっていた. 特に ニフェジピン服用の症例では顕著であった.タクロリム スの体内動態は併用薬を含め個体差が大きく, 副作用を さけるためにも TDM を的確に反映させた投与量の調節 が必要である.

タクロリムスの薬物動態は程度の差はあるが 2 相性の カーブを描き腸管循環を類推させるパターンを示してい た. また, CYP3A 酵素群は腸管内にも存在することが確 認されており腸管内での代謝酵素阻害もタクロリムス血 中濃度の上昇に何らかの影響を与えているものと推測し ている.

\section{4. 群馬大学医学部付属病院泌尿器科における平成 8 年} 度外来新患統計

小池 秀和, 佐々木 靖, 増田 広
中里 晴樹, 新屋 博之, 中野 勝也
久保田 裕, 清水 信明, 深堀 能立
林 雅道, 黒川 公平, 山中 英寿

(群馬大学)

群馬大学医学部附属病院は 1995 年度より特定機能病 院に指定されたため, 紹介患者が中心となる外来構成と なりつつある. 1996 年の外来新患患者の臨床統計を検討 した.

1 外来新患数：計 878 名であり, 男性は 629 名, 女性は 249 名であった. 男女比は $2.52: 1$ であった. 年齢的には,
男女とも 60〜69歳にピークを認めたが, 新生児を含む 幅広い年齢構成になっていた。紹介患者は 599 名, 全体 の $68.2 \%$ であり,他医よりの紹介が, 378 名，43.1\%を占 めていた。

2 症例数の多い疾患: 前立腺肥大症が最も多く 100 例 (14.7\%) であり，次いで, 結石が 60 例, 以下，移植・透 析関係 54 例, 前立腺癌 51 例, 腎癌 41 例, 膀胱炎 35 例, 無-乏精子症 31 例, 神経因性膀胱 29 例, 精巣腫瘍 25 例, 前立腺炎 24 例, 膀胱癌 19 例, の順であった. 前立腺癌, 腎癌, 透析関係, 精巣腫瘍が多いのが特徵だった。

\section{5. 癌末期医療の検討}

一第 1 報一 蘇生処置の有効性の検討

登丸 行雄

（桐生厚生総合病院）

1983 年から 1997 年の間に癌進行のため入院死亡した 94 例の, 蘇生措置の有効性を検討した。平均年齢 70.4 歳 (33-89). 心停止時の蘇生処置の内容によって A：蘇生処 置を行わなかった, B：心マッサージと AMBUbag で人 工呼吸を行った，C：BにDOA やメイロンなど薬剤投 与された，D：Cに挿管で呼吸管理をおこなった4群に 分類した. 各群の症例数は $43,28,13,10$ である. 10 分以上 の心拍をえられた症例数は 12 名 (ABCD 群 $0,0,5,7)$ で, 意識回復した症例はなかった。また $10 / 12$ は 24 時間以 内に再心停止し, Respirator の取り外しを希望した家族 が 2 症例にあった. 積極的に蘇生を試みればある程度心 拍再開を得られるが, 意識回復を伴う有意義な蘇生結果 は得られず, 家族の苦痛を増す結果に終わった。

\section{6. 癌末期医療の検討}

一第 2 報一 DNR (Do Not Resuscitate 蘇生処置禁 止) の検討

\section{登丸 行雄}

（桐生厚生総合病院）

蘇生処置を行うか否か家族と相談し DNR を決定した 症例を検討した. 対象症例は第 1 報と同様. 話し合った 群となかった群の症例数は 1983.3-1990.5 が 8：22, 1990. 6-1993.5 が 13：13，1993.6-1997.9が 34：4 と近年との割 合は増加している. 相談した 55 家族のうち 1 家族は挿 管を希望した. 相談がなかった 39 例のうち 31 例に蘇生 措置が施行され，同意があった 54 症例でも 19 症例に蘇 生処置が行われた.この 19 症例のうち9例は当直医ま たは看護婦によって, 1 例は誤嚥のため蘇生処置が行わ れた。DNR の相談は死亡前 2 日以内が 43\%，3-10 日が 26\%で，もうすこし早い時期に相談する方が良いと思わ れた. 数值化出来ないが DNR の相談があった家族の方 が死別を受容しやすい印象を受けた。 